\title{
ALBERTA's INSURANCE AMENDMENT ACT: MEANingful CHANGE OR A LONG ARROW WITH A SHORT Bow?
}

\author{
BARBARA BILLINGSLEY*
}

\section{INTRODUCTION}

A litigator I used to work with had a way with metaphors. He once described a legal argument as being a "long arrow with a really short bow" — the implication being that, while impressive and even intimidating at first instance, the argument really did not "fly" and failed to advance the law in a meaningful way. This description came to mind when the Alberta government announced last year that the major components of the province's long-awaited Insurance Amendment Act ${ }^{1}$ would take effect on 1 July 2012. ${ }^{2}$ Are the modifications contained in this statute worth the years of anticipation and consultation, or are the changes implemented by the legislation less significant for insurance contract law than the long reform process would suggest? In other words, does the statutory amendment achieve meaningful change by effectively addressing pressing insurance contract issues, or is this reform just a long arrow with a short bow?

In this legislative comment, I address this question by summarizing and evaluating some of the major reforms included in the IAA and the associated regulations. ${ }^{3}$ The reforms in question constitute a major restructuring of Part V of the Insurance Act, ${ }^{4}$ the segment of the statute which focuses on the rights and obligations of the parties to an insurance contract. The Alberta government has described the IAA as a form of consumer protection legislation, based on principles of "transparency, fairness, innovation, harmonization, and sustainability," and designed to "clarify and strengthen the rights [consumers] have when they enter into an insurance contract." This is the standard, then, that I apply to evaluate the amendments: does the IAA meaningfully and appropriately clarify and strengthen consumer rights in regards to insurance contracts?

To give context to this discussion, I begin in Part II of this comment with a brief overview of the legislative history of the IAA and the background leading to this statutory reform. In Part III, I discuss the major changes implemented by the new legislation and, in Part IV, I consider a few notable opportunities for change that are not taken up by the revised statute. In a brief closing section, I conclude that, while the IAA does make significant improvements

Professor, Faculty of Law, University of Alberta. This legislative comment is based on Barbara Billingsley, "The New Insurance Act: An Alberta Perspective” (Paper delivered at the Canadian Insurance Coverage Symposium, Vancouver, British Columbia, 14 October 2009) [unpublished].

SA 2008, c 19 [IAA]. As of the date of publication of this comment, the provisions of the IAA referenced in this comment have been incorporated into the Insurance Act,.

See OIC 325/2011, (2011) A Gaz 1, 580, [OIC 325/2011], which proclaimed the Act in force. The sections of the IAA which were excluded from the 13 July 2011 proclamation order took effect when the IAA received Royal Assent.

3 In selecting the portions of the IAA to comment on, I have intentionally omitted the amendments which define the risks which must be covered by a policy purporting to insure against fire (see IAA, supra note 1, ss 545(3)-(5) and the Fair Practices Amendment Regulation, Alta Reg 145/2001, s 5.7). This is because my comments are intended to focus on amendments relating to the rights and obligations of the parties, not to policy coverage per se.

4 Insurance Act, RSA 2000, c I-3 [unamended Act].

$5 \quad$ Alberta, Legislative Assembly, Alberta Hansard, 27th Leg, 1st Sess (27 May 2008) at 990 (Lloyd Snelgrove) [Hansard - 27 May 2008]. 
to Alberta's insurance contract law, some of the amendments have the potential to cause confusion in the law and some important issues are not resolved by the revised legislation.

While my focus is on the changes made under the $I A A$, much of the commentary in this legislative comment is relevant to recent amendments to British Columbia's insurance legislation, which mirror Alberta's statutory reforms in many respects. ${ }^{6}$ The issues discussed in this comment may also be pertinent to future statutory reforms in other provinces, as it has been suggested that the changes implemented in Alberta and British Columbia will ultimately serve as templates for legislative reform in other jurisdictions. ${ }^{7}$

\section{BACKground to AlBERTA's InSURANCE AmENDMENT ACT}

The IAA is the latest and most far-reaching in a series of insurance law reforms implemented by the Alberta government over the past 12 years. ${ }^{8}$ Although the Alberta government has stated that the IAA constitutes the second phase of the provincial government's decision in the 1990s to overhaul Alberta's insurance legislation, ${ }^{9}$ the majority of the IAA seems to be more directly related to the Supreme Court of Canada's 2003 call for the fundamental statutory reform of provincial insurance legislation. ${ }^{10}$ In KP Pacific Holdings Ltd. v. Guardian Insurance Co. of Canada ${ }^{11}$ and Churchland v. Gore Mutual Insurance, ${ }^{12}$ the Supreme Court was asked to determine whether the limitation period prescribed by the

Insurance Amendment Act, 2009, SBC 2009, c 16. In November 2005, the British Columbia government began a review of the province's insurance legislation, which included a public consulation process that took place in 2007 (see British Columbia Ministry of Finance, Insurance Act Review Discussion Paper (Victoria, BC: Ministry of Finance, 2007), online: British Columbia Ministry of Finance <http://www. fin.gov.bc.ca/cep/fcsp/InsuranceAct_Review_DiscussionPaper.pdf $>$ ). The legislature first introduced Bill 40, Insurance Amendment Act, 2008, 4th Sess, 38th Parl, British Columbia, 2008 (first reading 30 April 2008), but the bill died on the order paper (see British Columbia, Legislative Assembly, Official Reports of Debates of the Legislative Assembly (Hansard), 4th Sess, 38th Parl, Vol 31, No 8 (30 April 2008) at 11772). The legislation was re-introduced on 15 September 2009 as Bill 6, Insurance Amendment Act, 2009, 1st Sess, 39th Parl, British Columbia, 2009 (assented to 29 October 2009), SBC 2009, c-16. In February 2010, the British Columbia government commenced a consultation process on the associated regulations (see British Columbia Ministry of Finance, Insurance Act Regulations Discussion Paper (Victoria, BC: Ministry of Finance, 2010), online: British Columbia Ministry of Finance <http://www.fin.gov.bc.ca/prs/fcsp/insurance_regs_discussion_paper.pdf >). By Order in Council dated 1 December 2011, the bulk of the amended statute and the new regulations were proclaimed in force as of 1 July 2012 (see British Columbia OC 589/2011).

Hansard - 27 May 2008, supra note 5 at 990. At present, however, no other jurisdiction has tabled legislation to fully reform its insurance legislation along the lines of the Alberta or British Columbia amendments.

8 In 1999, the Alberta legislature passed the Insurance Act, SA 1999, c I-5.1, which implemented substantial changes relating to the regulation of insurance companies and the licencing of insurance agents. In 2004, Alberta's insurance legislation was amended (see Insurance Amendment Act, 2003, (No 2), SA 2003, c 40) and new regulations were passed with regard to the province's automobile insurance scheme. For a discussion of the regulatory reforms, see Peter B Michalyshyn, "The Diagnostic and Treatment Protocols Regulation and the Minor Injury Regulation: Review and Commentary" (2005) 42:3 Alta L Rev 923. In general, these automobile insurance reforms implemented a minor injury cap on non-pecuniary damages for soft-tissue injuries and increased no-fault benefits for persons injured in automobile accidents.

$9 \quad$ See Government of Alberta, We Want Your Input: Consultation on Proposed Regulations for the Amended Insurance Act (Edmonton: Alberta Finance and Enterprise, 2009) at 1, online: Alberta Treasury Board and Finance <http://www.finance.alberta.ca/publications/insurance/2009_0615_ consultation_insurance_regs.pdf>.

See Hansard - 27 May 2008, supra note 5 at 990, where, in moving second reading of Bill 11, Mr. Snelgrove stated: "The Supreme Court of Canada encouraged all provinces to clarify and modernize insurance contracts several years ago. By addressing this issue with the introduction of this legislation, Alberta will remain a national leader." See also Alberta, Legislative Assembly, Alberta Hansard 27th Leg, 1st Sess (14 October 2008) at 1296. 
fire insurance section of British Columbia's insurance legislation applied to property insurance contracts covering a wide range of risks. In deciding that the fire insurance provisions did not apply, the Supreme Court described the classification of insurance contracts under provincial insurance statutes as antiquated and inconsistent with modern insurance practices. ${ }^{13}$ In particular, the Court criticized the fact that provincial insurance statutes still contain segments devoted to "fire insurance" contracts, when most contemporary property insurance policies provide coverage for a wide variety of risks, including, but not limited to, fire loss. ${ }^{14}$ The Supreme Court called for legislative reform to address this problem:

[I]t is our hope that legislators will rectify the situation by amending the Insurance Act to provide specifically for comprehensive policies. In an insurance era dominated by comprehensive policies, it is imperative that Canada's Insurance Acts specifically and unambiguously address how these statutes are to operate and the rules by which comprehensive policies are to be governed. ${ }^{15}$

Alberta and British Columbia are the first provinces to take up the Supreme Court's plea for reform. Acting in accordance with the Trade, Investment and Labour Mobility Agreement ${ }^{16}$ entered into by Alberta and British Columbia in 2006, the two provinces collaborated on developing legislative reforms to address the Supreme Court's concern and to harmonize insurance contract legislation between the two provinces. ${ }^{17}$

Bill 42, the Insurance Amendment Act, 2007, ${ }^{18}$ was tabled in the Alberta legislature in the spring of $2007^{19}$ as the province's first attempt to overhaul Part V of the unamended Act. The Bill was not passed in order "to allow for further public consultation." ${ }^{20}$ Subsequently, Bill 11, the Insurance Amendment Act, 2008, ${ }^{21}$ was introduced in the Alberta legislature on 30 April 2008 and received Royal Assent on 4 November 2008. While a handful of the IAA amendments took effect immediately, the implementation of the bulk of the changes, including most significantly the modification of Part V of the unamended Act, was delayed in order for the Alberta government to pass necessary regulations. ${ }^{22}$ Public consultation on the proposed regulations was conducted in the summer and fall of $2009 .^{23}$ Ultimately, an Order in Council was issued in 2011 proclaiming the regulations and the previously

KP, supra note 11 at paras 16-18; Churchland, ibid at para 4.

$K P$, ibid at paras 4-5; Churchland, ibid.

$K P$, ibid at para 20.

The purpose of this agreement is to facilitate trade and labour mobility between Alberta and British Columbia by reducing rules or conflicts in provincial legislation which restrict the free movement of goods and services. See Trade, Investment and Labour Mobility Agreement (April 2009), online: TILMA <http://www.tilma.ca/pdf/TILMA_Agreement_April2009.pdf>.

17 See Alberta Government News Release, "Alberta and B.C. Collaborate to Improve Insurance Legislation” (30 April 2008), online: Alberta Government <http://alberta.ca/acn/200804/234069C246 A0A-D451-829A-FBBAA44A9E78851F.html>.

18 Bill 42, Insurance Amendment Act, 2007, 3d Sess, 26th Leg, Alberta, 2007 (first reading 12 June 2007). Alberta, Legislative Assembly, Alberta Hansard, 26th Leg, 3rd Sess (12 June 2007) at 1693.

Hansard - 27 May 2008, supra note 5 at 990.

Bill 11, Insurance Amendment Act, 2008, 1st Sess, 27th Leg, Alberta, 2008 (assented to 4 November 2008), SA 2008, с 19.

22 See Government of Alberta, Treasury Board and Finance, Insurance Legislation - Regulation Consultation, online: Alberta Treasury Board and Finance <http://www.finance.alberta.ca/publications/ insurance/regs_consultation/index.html>. Ibid. 
unproclaimed provisions of the $I A A$ to be in force as of 1 July $2012 .{ }^{24}$ This means that the most significant parts of the IAA finally took effect nearly a decade after the Supreme Court of Canada's call for reform in KP and Churchland, and almost four years after the amendment statute was passed by the legislature. ${ }^{25}$

\section{Major Changes Under THE IAA}

\section{A. NeW Classes OF InSURANCE CONTRACTS}

The IAA reduces, by nearly half, the number of statutory sub-parts identifying separate categories of insurance. Part V of the unamended Act has ten sub-parts: a general sub-part applying to all insurance contracts except for life insurance; and separate sub-parts which apply respectively to fraternal societies, fire insurance, life insurance, automobile insurance, accident and sickness insurance, livestock insurance, hail insurance, weather insurance, and mutual insurance. The IAA reclassifies Part V into six sub-parts: a general sub-part applicable to all insurance contracts except for life insurance, accident and sickness insurance, and reinsurance; and dedicated sub-parts applying respectively to automobile insurance, fraternal societies, hail insurance, life insurance, and accident and sickness insurance.

A major element of this reclassification is the incorporation of the previous fire insurance sub-part into the new general sub-part of the amendment statute. The provisions in the general sub-part of the IAA apply to all property and liability policies, unless expressly stated otherwise. In particular, all of the statutory conditions in the general sub-part apply to comprehensive or multi-peril policies of property insurance. ${ }^{26}$ This modification resolves the central problem which was put before the Supreme Court in KP and Churchland and directly responds to the Court's call for legislative reform. ${ }^{27}$ This is a significant, practical change which aligns Alberta's insurance law with the current industry practice of issuing comprehensive coverage property insurance policies and eliminates any debate as to the application of statutory conditions to property insurance contracts providing coverage against multiple risks.

\section{B. Limitation Periods}

The IAA and related regulations make significant changes to the limitation periods for commencing legal action on most types of insurance contracts. These changes relate to: (1) the type of insurance contracts affected by the limitation periods prescribed by the insurance

See OIC 325/2011, supra note 2. The relevant regulations are: the Classes of Insurance Regulation, Alta Reg 144/2011; the Fair Practices Amendment Regulation, supra note 3; the Miscellaneous Provisions Amendment Regulation, Alta Reg 146/2011; the Enforcement and Administration Amendment Regulation, Alta Reg 147/2011; the Transitional (Insurance Amendment Act, 2008-Part5) Regulation, Alta Reg 185/2011.

25 British Columbia’s statutory reforms have had a similarly protracted history in regards to passage and proclamation. For further discussion of the recent amendments to British Columbia's legislation, see supra note 6.

26 By the combined effect of the IAA, supra note 1, s 540 and the Fair Practices Amendment Regulation, supra note 3, s 5.8, the statutory conditions in section 540 do not apply to automobile, hail, surety, mortgage, title, credit protection, or travel insurance and some of the statutory conditions do not apply to general liability policies.

$27 \quad$ See the discussion in Part II of this comment. 
statute; (2) the length of the prescribed limitation periods; and (3) the obligation of insurance companies to advise their clients of the relevant limitation period.

\section{TyPE OF InSURANCE CONTRACTS AFFECTED}

The limitation periods set out in the unamended Act apply only to particular types of insurance contracts. For instance, the unamended Act provides specific limitation periods relating to contracts of fire insurance, life insurance, automobile insurance, and accident and sickness insurance. ${ }^{28}$ However, because the general sub-part does not contain its own limitation period, insurance contracts that fall within the general sub-part of the unamended Act are subject to the limitation period prescribed by Alberta's Limitations Act. ${ }^{29}$ In contrast, the $I A A$ provides limitation periods for contracts falling within the general sub-part, ${ }^{30}$ as well as for those captured by the specific sub-parts. ${ }^{31}$ This means that the IAA prescribes limitation periods for all insurance contracts, making it unnecessary to look outside of the insurance statute to identify the relevant limitation period. This reform is consistent with the objective of making the IAA more consumer-friendly, as potential litigants can rely on a single statute to determine the relevant limitation period for commencing action on any insurance contract.

Nevertheless, the limitation periods prescribed by the IAA continue to be needlessly scattered throughout the insurance statute. The IAA would be more consumer-friendly if potential litigants could look to a single statutory section to determine the applicable limitation period. To simplify the situation, legislators could have removed the limitation provisions from the insurance statute entirely, and centralized the limitation periods for insurance contracts, along with all other contracts, in the Limitations Act. ${ }^{32}$ As it stands, a potential insurance contract litigant still needs to know that the limitation period governing his or her claim is not found in the Limitations Act, and then has to locate the appropriate limitation period provision within the IAA. Admittedly, this difficulty is mitigated by the insurer's new obligation to advise the insured of the relevant limitation period (discussed below). Still, there does not seem to be a principled reason for housing the limitation periods applicable to insurance contracts in a separate statute from the limitation periods applicable to all other contracts, especially since the IAA is intended to harmonize the length of these limitation periods.

\section{Length OF THE PRESCRIBEd Limitation PERIODS}

In combination, the unamended Act and Alberta's Limitations Act provide for a mix of one and two year limitation periods governing insurance contracts. The limitation period prescribed for particular types of insurance contracts under the unamended Act is typically

Supra note 4, ss 549, statutory condition 14 (fire insurance), 590 (life insurance), 614, statutory condition 6(3) (automobile insurance), 671, statutory condition 12 (accident and sickness insurance). RSA 2000, c L-12, s 3.

IAA, supra note 1 , s 526 .

See e.g. ibid, ss 558 (automobile insurance), 636 (hail insurance), 677 (life insurance), 708 (accident and sickness insurance).

This was the recommendation of the Alberta Law Reform Institute (ALRI). See ALRI, Limitations Act: Standardizing Limitation Periods for Actions on Insurance Contracts (Edmonton: ALRI, 2003) at 29, online: ALRI <http://www.law.ualberta.ca/alri/docs/fr090.pdf>. 
one year, ${ }^{33}$ whereas the limitation period on contracts falling under the Limitations Act is two years. ${ }^{34}$ The inconsistency in limitation periods under the unamended Act has been identified as the source of serious practical concern: "Inconsistent limitation periods have caused confusion for both insured and for lawyers, and have resulted in a considerable amount of litigation over missed limitation periods." 35

In accordance with long-standing reform recommendations, ${ }^{36}$ the $I A A$ rectifies this situation by prescribing a two year limitation period for most insurance contract actions. ${ }^{37}$ The IAA also expressly incorporates, for the purposes of all insurance contract actions, section 5 of Alberta's Limitations Act, which suspends the operation of the limitation period while the claimant is under a disability. ${ }^{38}$ These changes go a long way toward achieving uniformity of limitation periods in the area of insurance law. The limitation period is significantly harmonized, both in regards to different types of insurance contracts and in regards to insurance contracts, as compared to other types of contracts. However, the IAA's commitment to a two year limitation period and to uniformity with the time periods set out in the Limitations Act is, disappointingly, incomplete in several ways.

First, the IAA retains a one year limitation period for judgment creditor actions brought against automobile liability insurers. ${ }^{39}$ It is tempting to rationalize this anomaly on the basis that, being a purely statutory cause of action, the judgment creditor action is fundamentally different from an ordinary insurance contract action. However, the problem with this explanation is that the IAA also establishes a statutory judgment creditor action against a general liability insurer, and the statute does not impose a one year limitation period on that action. ${ }^{40}$ The one year limitation period, therefore, seems arbitrary and causes the potential for unnecessary confusion.

Second, the commencement date of the two year limitation period provided in the IAA varies with the type of insurance at issue. For example, the limitation period for property insurance contracts runs from "the date the insured knew or ought to have known that the loss or damage occurred," 41 while the limitation period for a property damage claim under an automobile insurance policy runs from "the occurrence of the loss or damage." 42 In other words, the IAA retains the unamended Act's approach of applying the principle of

See e.g. the statutory provisions listed supra note 28. There are some exceptions to the one year rule. For instance, in the case of life insurance, an action must be commenced within one year of the insurer being provided with evidence relating to the death of the insured or within six years of the date of the insured's death (unamended Act, supra note 4, s 590).

Supra note 29, s 3(1)(a).

ALRI, supra note 32 at vii.

Ibid at 31.

See supra notes 30-31. Note that section 677 of the IAA, supra note 1, relating to life insurance, retains the option of an action being commenced within one year of the submission to the insurer of evidence relating to the death of the insured or within six years of the date of death.

IAA, ibid, s 527; Limitations Act, supra note 29, s 5.

IAA, ibid, s 579(2).

Although the IAA does not specifically identify the limitation period for the judgment creditor action against a general liability insurer, the relevant limitation period seems to be two years from the date that the writ of enforcement against the insured is returned unsatisfied. This conclusion is derived from the combined effect of section 534 (which provides for this judgment creditor action) and section 526 (which provides the general two year limitation period for actions on policies falling under the general sub-part).

$41 \quad$ Supra note 1 , s 526(1)(a).

$42 \quad$ Ibid, s 558(1)(a). 
discoverability to select types of insurance contracts. By comparison, under the Limitations Act, the principle of discoverability applies to the two year limitation period for all contract claims. ${ }^{43}$ There is no obvious reason why the IAA could not have mirrored the Limitations Act in this regard. In fact, in examining this discrepancy in the context of the unamended Act, the ALRI concludes that there is no principled reason, in policy or law, for the creation of special commencement dates for limitation periods pertaining to certain types of insurance contracts. ${ }^{44}$ Further, the ALRI notes that a limitation period that commences on the date of loss is unfair to the insured because the limitation period starts to run before the insurer has committed the contract breach — that is, the allegedly wrongful denial of coverage - which is the basis for the insured's cause of action. ${ }^{45}$ Finally, in response to the argument that an insurer's ability to investigate a claim might be prejudiced by a limitation period that incorporates the discoverability rule, the ALRI concludes that this concern is alleviated by the insured's statutory obligations (retained under the $I A A$ ) to provide timely notice and proof of loss to the insurer. ${ }^{46}$

Third, the Limitations Act specifically provides that the relevant limitation period for an ordinary contract action can be extended by the terms of the contract, though it cannot be shortened. ${ }^{47}$ Under the $I A A$, the limitation periods prescribed for insurance contracts cannot be extended or curtailed. ${ }^{48}$ The prohibition against shortening the limitation period makes sense as a consumer protection mechanism, but the IAA's prohibition against extending the limitation period is out of step with the Limitations Act, and seems odd for a statute that purports to be sensitive to consumer needs. An insured and an insurer should be free to agree to an extended limitation period if that arrangement suits both their purposes in the context of a particular contract. ${ }^{49}$ Further, because the IAA identifies limitation periods for all insurance contracts, the parties to insurance contracts which would have previously been captured by the Limitations Act (such as the parties to general liability contracts) are worse off under the amended system. Under the old regime, they were free to negotiate for an extended limitation period; under the $I A A$, they are prevented from doing so. The ability to contractually extend a limitation period would benefit the insured and would enhance, not offend, the objectives of the IAA. As it stands, the IAA forces an insured to rely on the doctrines of waiver or estoppel to argue that an insurer did not intend to enforce the statutory limitation period. It would be much simpler for both parties if they could agree, by contract, to a specific, extended limitation period.

Supra note 29, s 3(1)(a), subject to the final limitation period of 10 years.

Supra note 32 at 30 .

Ibid at 31.

Ibid.

Supra note 29, s 7.

Where the limitation periods are incorporated as statutory conditions, the IAA expressly provides that the statutory conditions cannot be altered by contract (see for example, section 636, statutory condition 16 , pertaining to hail insurance). Where the limitation periods are not incorporated into statutory conditions but are set out in regular statutory provisions (for example, section 558 pertaining to automobile insurance and section 677 pertaining to life insurance), section 515 applies to prohibit an insurer from making a contract that is inconsistent with the IAA. So, in either case, the limitation periods cannot be formally extended. Interestingly, in contrast to the IAA, British Columbia's Insurance Amendment Act, 2009, supra note 6, s 2.4(b), specifically authorizes the extension, by agreement, of the statutory limitation periods.

While, admittedly, laypeople purchasing insurance contracts may have little motivation to contract for an extended limitation period, sophisticated insureds entering into large scale insurance contracts may want to extend the limitation period in certain instances. 
Finally, although the IAA adopts the Limitations Act provisions suspending the running of a limitation period while the claimant is under a disability, the IAA does not incorporate the Limitations Act provisions suspending the running of a limitation period while the claimant is a minor. ${ }^{50}$ Once again, this inconsistency with the Limitations Act is inexplicable and is likewise inconsistent with the IAA's goal of consumer protection because it restricts an insured's ability to sue an insurer.

Overall, the IAA's failure to fully embrace a standard two year limitation period with a consistent definition of a commencement date and with flexibility to extend the limitation period by contract or in other appropriate circumstances means that, in Alberta, limitations law for insurance contracts remains distinct from limitations law relating to other contracts. As a result, at least some of the confusion over limitation periods that occurred under the unamended Act can be expected to continue. In this regard, the IAA fails to live up to its goal of clarifying consumer rights under insurance contracts.

\section{Obligation of InSURERS TO AdVise Clients OF RELEVANT LIMITATION PERIODS}

Under the unamended Act, insurers are not responsible for informing their clients about the relevant limitation periods for suing the insurer for coverage ${ }^{51}$ As part of its consumer protection mandate, however, the IAA and associated regulations hold insurers responsible for providing this advice to their insureds, both in general and specific terms. The $I A A$ requires all insurance policies to provide general notice of the limitation period issue by including the following generic statement on the insurance policy: "Every action or proceeding against an insurer for the recovery of insurance money payable under the contract is absolutely barred unless commenced within the time set out in the Insurance Act." 52

The Fair Practices Amendment Regulation goes further, requiring insurers to give written notice of the specific limitation period applicable to existing and potential policy claimants. ${ }^{53}$ The regulation specifies the time frame for giving such notice, and requires the insurer to identify the legislation or regulation that sets out the limitation period. If the insurer fails to fulfil this requirement, the regulation authorizes a court to extend the limitation period or to grant another appropriate remedy. ${ }^{54}$ The insurer is relieved from this notice obligation if, at the time notice is required, the insurer knows that the claimant is represented by legal counsel. ${ }^{55}$

See the Limitations Act, supra note 29, s 5.1(2). Once again, this is a point of difference between the IAA and British Columbia's Insurance Amendment Act, 2009, supra note 6, s 2.4. The latter provision incorporates the British Columbia’s Limitation Act, RSBC 1996, с 266, allowing for the suspension of the limitation period where the claimant is a minor.

51 However, waiver or estoppel might apply if the insurer led the insured to believe that a limitation period would not be enforced. See Maracle v Travellers Indemnity Co of Canada, [1991] 2 SCR 50. See also IAA, supra note 1 , s 521.

52 IAA, ibid, ss 516(3)(j) (general insurance), 645(1)(g) (life insurance), 700(1)(f) (accident and sickness insurance).

$53 \quad$ Supra note 3, s 5.3(2). There are narrow exceptions provided in sections 5.3(5) and (6) relating to claims under section B of an automobile insurance policy and non-disability coverage under a group accident and sickness policy respectively.

$54 \quad$ Ibid, s 5.3(4).

$55 \quad$ Ibid, s 5.3(7). 
The notice obligations instituted by this regulation impose an extraordinary obligation on insurers. In essence, and as demonstrated by the fact that insurers are relieved of this obligation where the insured is known to have legal counsel, the regulation requires insurers to provide legal advice to their insureds with regard to the insured's rights under the contract. If the insurer is wrong about the advice (which is a real possibility, given the varied commencement dates for the limitation periods set out in the statute and the uncertainties necessarily associated with determining the commencement date where the discoverability rule applies), the statute necessarily sets up a waiver or estoppel argument for the insured to rely on if the insurer later defends litigation on the basis of a different limitation date. While this certainly serves the legislative objective of consumer protection, it does so by creating a serious imbalance in the legal rights of the parties to an insurance contract. It also provides another potential issue for litigation: did the insurer provide notice in accordance with the detailed requirements of the regulation? The notice requirement may also increase administrative and legal costs for insurers, which will inevitably be transferred to consumers via premium charges.

\section{RECOVERY BY INNOCENT CO-INSUREDS}

In Scott v. Wawanesa Mutual Insurance, ${ }^{56}$ a majority of the Supreme Court of Canada barred an insured homeowner from recovering insurance proceeds for a loss intentionally caused by the homeowner's son, even though the homeowner did not cause or contribute to the loss. Although based on what the majority found to be the clear wording of an express policy exclusion, the majority's interpretation of the contract has been criticized as being unduly formalistic and giving rise to a patently unfair outcome - that is, the denial of coverage to an innocent insured. ${ }^{57}$ This criticism is embraced by the $I A A$, which seeks to prevent similar findings in the future. Specifically, section 541 of the IAA expressly provides that a contract clause limiting coverage for loss caused by an intentional or criminal act of an insured does not bar recovery by a co-insured who did not commit, assist in, or consent to the act, or who did not have either actual or constructive knowledge that the act would cause loss or damage. By regulation, this saving provision only applies for the benefit of coinsureds who are natural persons (as opposed to corporations). ${ }^{58}$ The regulation also provides that, in order to rely on section 541, an innocent co-insured must fully co-operate with the insurer's investigation of the loss and produce, as required by the insurer, all documents relevant to the loss. ${ }^{59}$

These modifications are a significant improvement in insurance law. Consistent with the consumer protection goals of the $I A A$, these changes clarify an area of law which has been subject to divergent judicial opinion on the basis of subtle differences in policy wording and public policy perspectives. Most importantly, by insisting that the insurer's liability for coverage be treated severally rather than jointly, the new legislative scheme recognizes, as a practical reality, that co-insureds cannot always control one another's behaviour. In short,

56 [1989] 1 SCR 1445 [Wawanesa].

57 See e.g. Erik Knutsen, “The Innocent Co-Insured: Severable Coverage Could Protect Innocent Family Members,” The Lawyers Weekly (10 June 2011), online: The Lawyers Weekly <http://www.lawyers weekly.ca/index.php?section=article\&articleid=1436>. This is also the perspective adopted by the minority of the Court in the Wawanesa case itself.

58 The Fair Practices Amendment Regulation, supra note 3, s 5.9(1). Ibid, s 5.9(2). 
the new system rectifies the inherent unfairness of permitting insurers to avoid paying insurance proceeds to insureds who had no role in bringing about the loss.

\section{WAIVER, ESTOPPEL, AND RELIEF FROM FORFEITURE}

It is a basic principle of insurance law that, where an insured has failed to comply with its obligations under an insurance contract, the insured may, nonetheless, be entitled to coverage if the principles of waiver, estoppel, or relief from forfeiture apply. ${ }^{60}$ Under the unamended Act, the insured's ability to rely on the common law doctrine of waiver is restricted to circumstances where the waiver by the insured was "stated in writing and signed by a person authorized for that purpose by the insurer." ${ }^{61}$ The unamended Act does not expressly deal with the doctrine of estoppel, although courts, nonetheless, have applied estoppel to the benefit of insureds, sometimes in order to escape the statutory restrictions on the waiver doctrine. ${ }^{62}$ The unamended Act includes two relief from forfeiture provisions: one which empowers a court to relieve an insured from the consequences of imperfect compliance with a statutory condition or another matter relating to the insured loss, ${ }^{63}$ and one which authorizes a court to relieve the insured from the consequences of imperfect compliance with a contract term or condition relating to the proof of loss. ${ }^{64}$ Simultaneously, Alberta's Judicature Act ${ }^{65}$ more generally authorizes courts to "relieve against all penalties and forfeitures." This distinction between the relief from forfeiture provisions in the unamended Act and those in the Judicature Act is common in provincial legislation and gives rise to a question as to whether, and to what extent, the specific relief from forfeiture provisions in insurance statutes preclude application of the general statutory provision found in other legislation. This is an important and practical issue because, for example, the relief from forfeiture provisions in the unamended Act do not apply to life insurance contracts and are expressly restricted to post-loss breaches by the insured, while the general relief from forfeiture power does not include such limitations. The Supreme Court of Canada has opined that the relief from forfeiture provisions in insurance legislation do not preclude application of the general relief power found in other legislation, ${ }^{66}$ however, the exact relationship between the two sources of relief remains undefined by case law. ${ }^{67}$ Further, Canadian case law has failed to clearly define "imperfect compliance," which would give rise to relief under the terms of the unamended Act, and "non-compliance," which would fall outside of the unamended Act's relief provisions. ${ }^{68}$

In some minor respects, the IAA clarifies and simplifies the law regarding waiver, estoppel, and relief from forfeiture. First, while maintaining the unamended Act's restriction of the waiver doctrine to circumstances where the insurer provides written notice that the

See Barbara Billingsley, General Principles of Canadian Insurance Law, 1st ed (Markham: LexisNexis, 2008) at 198-224.

Supra note 4, s 517(1).

Billingsley, supra note 60 at 219 .

Supra note 4, s 515. In Falk Bros Industries Ltd v Elance Steel Fabricating, [1989] 2 SCR 778 at 782, the Supreme Court of Canada held that this reference to "[an]other matter or thing required to be done" means that the statutory provision applies to ordinary contract terms as well as to statutory conditions. See the unamended Act, ibid, s 521.

RSA 2000, c J-2, s 10.

Saskatchewan River Bungalows Ltd v Maritime Life Assurance, [1994] 2 SCR 490 at 505.

For further discussion of this issue, see Billingsley, supra note 60 at 201-207.

Ibid, at 205-207. 
insured is excused from its contractual obligation, the IAA also expressly authorizes the court's application of the principle of estoppel where the requirements of waiver cannot be met. ${ }^{69}$ This modification overcomes any confusion as to whether the doctrine of estoppel can be relied upon by an insured to avoid the consequences of failing to comply with a contract provision where the requirements of waiver are not met. Second, in regards to relief from forfeiture, the IAA merges the two statutory provisions from the unamended Act into a single section, which provides as follows:

If the Court considers it inequitable that there has been a forfeiture or avoidance of insurance, in whole or in part, on the ground that there has been imperfect compliance with

(a)

a statutory condition, or

(b)

a condition or term of the contract

as to the proof of loss to be given by the insured to the claimant or another matter or thing done or omitted to be done by the insured or the claimant with respect to the loss, the Court may relieve against the forfeiture or avoidance on any terms it considers just. ${ }^{70}$

This combination of the two statutory provisions from the unamended Act obviously simplifies the relief from forfeiture provision. Despite these improvements, however, significant problems in clarity remain. Most notably, the critical issue as to whether this relief from forfeiture provision supercedes or acts in substitute for the relief provision in the Judicature Act is not resolved. The IAA's relief from forfeiture provision is still inapplicable to life insurance contracts, and the $I A A$ does not expressly indicate that an insurance contract or an insured's conduct which is not captured by section 520 may benefit from relief under the Judicature Act. ${ }^{71}$ Further, no statutory definition of "imperfect compliance" is offered. Accordingly, the distinction between actions which constitute imperfect compliance and those which constitute non-compliance remains subject to judicial definition on a case by case basis.

\section{E. Procedures Relating to Contract Rights}

The IAA makes several changes to procedures relevant to the enforcement of insurance contracts. For instance, modifications are made in regards to procedures for: subrogation rights; the resolution of valuation disputes; the insurer's ability to unilaterally terminate a contract; the insurer's ability to rely on the terms set out in interim binders and in insurance policies; and notice provisions. Generally, as described briefly below, the changes in each of these areas reflect the legislative goal of consumer protection by simplifying processes. Further, with few exceptions, the amendments favour the insured by imposing additional restrictions on the insurer. The exceptions are those provisions relating to subrogation rights

Supra note 1, s 521(1).

Ibid, s 520.

The IAA is, once again, distinct from British Columbia's Insurance Amendment Act, 2009, supra note 6. Section 10 of the British Columbia statute specifically states that the relief from forfeiture provisions operate "[w]ithout limiting section 24 of the Law and Equity Act," which is British Columbia's statutory provision containing a general relief from forfeiture power. 
and the resolution of valuation disputes, where the legislation seems to strike a balance in protecting the interests of both parties to the contract.

\section{SubROGATION RightS}

The IAA consolidates the unamended Act's separate statutory subrogation provisions, relating to fire insurance and automobile insurance respectively, into a single statutory provision which is included in the general sub-part of the Act and which, therefore, applies to most types of insurance. ${ }^{72}$ While retaining the unamended Act's modification of the common law so as to allow an insurer to exercise a right of subrogation before fully indemnifying the insured, the amended provision also provides a method for determining whether, in circumstances of partial indemnity, the subrogated action will be controlled by the insurer or by the insured. Under the unamended Act, this procedure was prescribed only for automobile insurance contracts; the IAA makes this procedure applicable to all insurance contracts which fall under the general sub-part of the statute.

\section{VAluation Dispute Resolution}

The IAA substitutes a new dispute resolution procedure for the unamended Act's appraisal system. ${ }^{73}$ Apart from altering some of the nomenclature (for example, an "appraiser" under the unamended Act is a "representative" under the $I A A$ ) and imposing restrictions on who can serve as a party's representative, the most significant amendments relate to the appointment of an umpire and to the mechanisms available for enforcing the resolution proceedings. Under the unamended Act, if the parties cannot agree on an umpire to resolve their differences, an umpire may be appointed by the court. Under the IAA, a representative may apply, on notice, to the Superintendent. The Superintendent must select an umpire from names submitted by the representatives and, in resolving the dispute, the umpire is expressly bound by the rules of procedural fairness. Provisions are also made for the court to become involved if a party does not comply with its obligation to appoint a representative. In particular, the court is empowered to appoint a representative and to award solicitor and client costs against the uncooperative party. The Fair Practices Amendment Regulation adds to this statutory process by requiring an insurer to advise the insured of the dispute resolution process within a specified time frame after the insurer determines that a dispute as to valuation has arisen or after the insured has filed a proof of loss. ${ }^{74}$ The notice must include a copy of section 519 of the IAA.

\section{TERMINATION OF THE CONTRACT BY THE INSURER}

The IAA alters, in particular instances, the circumstances and requirements for terminating an insurance contract. First, with regard to life insurance and accident and sickness insurance, the $I A A$ authorizes a court, on application by a person whose life or well-being is insured, to terminate or alter the terms of the insurance contract if: (1) the applicant is not the insured under the contract, and (2) the court is satisfied that the applicant reasonably believes 
that his or her life or health might be endangered by the continuation of the contract. ${ }^{75}$ These provisions are new to Alberta's insurance legislation, though they are apparently inspired by similar termination provisions in other jurisdictions. ${ }^{76}$ The IAA provisions are broad in scope, enabling an applicant to have a termination order issued even where the party contracting for the insurance retains an insurable interest in the life or well being of the applicant. ${ }^{77}$ Second, whereas the unamended Act permits an insurer to terminate a policy "forthwith" by written notice if a premium payment is not honoured, ${ }^{78}$ the $I A A$ provides that, even in this circumstance, the unilateral termination provisions in relevant statutory or policy conditions apply. ${ }^{79}$ Since most contracts (excepting life insurance and general liability insurance) are subject to statutory conditions, the notice provisions in the statutory conditions will apply in most cases. As per the unamended Act, the statutory conditions in the IAA provide for a 15 day notice period if the notice is given by mail, and a five day notice period if the notice is personally delivered. ${ }^{80}$ However, the IAA calculates this time period differently than the unamended Act. In the latter statute, the 15 days runs from the day after the notice is received by the post office to which it is addressed. Under the IAA, the 15 days starts to run on the day the notice is delivered to the insured's postal address. ${ }^{81}$

\section{INTERIM BINDERS AND INSURANCE POLICIES}

The $I A A$ requires an insurer to advise an insured of the existence and contents of interim binders and insurance policies if the terms vary from what the insured would expect. Specifically, with regard to interim binders, the IAA states that a contract that takes effect prior to the issuance of the policy is deemed to contain the terms and conditions of the insurer's relevant standard policy and that the insurer cannot rely on a term or condition if the insured was not given written notice of same and if the insured cannot reasonably comply with the term without such notice. ${ }^{82}$ This provision is completely new to Alberta's insurance legislation. In regards to non-interim policies, the IAA mirrors the unamended Act's provision that an insurance contract is deemed to be in accordance with the terms of the application unless the insured is notified otherwise, and, in which case, the insured has two weeks to reject the policy. ${ }^{83}$ The IAA goes further, however, expressly setting out the insurer's obligations to refund a specified portion of the insurance premium as soon as practicable if

Supra note 1, ss 648, 717 respectively.

See Hansard - 27 May 2008, supra note 5 at 991, where, in moving for second reading of Bill 11, Mr. Snelgrove stated: "Similar to legislation in Manitoba the amendment will allow a person to cancel an insurance contract on their life if they feel their life or health is at risk because of the contract." With regard to life insurance, the relevant provision of Manitoba's statute is the Insurance Act, RSM 1987, c I40, CCSM c I40, s 155(4) which provides: "A person whose life is insured may, where insurable interest no longer exists, apply to the court for an order requiring the insurer to immediately terminate the policy and pay over to the policy owner any value that exists in the policy.”

This is broader than the provision in the Manitoba statute, which is relevant only where the purchaser of the insurance contract no longer has an insurable interest in the life of the person insured. See supra note 76.

Supra note 4, s 518(3).

Supra note 1, s 522(3).

See e.g. unamended Act, supra note 4, s 549, statutory condition 5(1) as compared to IAA, ibid, s 540, statutory condition 5(1)(a).

See e.g. unamended Act, ibid, s 549, statutory condition 5(5) as compared to IAA, ibid, s 540, statutory condition 5(4).

IAA, ibid, s 517.

The unamended Act, supra note 4, s 547; IAA, ibid, s 518(1). 
the policy is rejected by the insured. ${ }^{84}$ For good measure, the amended provision also states that if the insured does not reject the policy within two weeks, he is deemed to accept it. ${ }^{85}$

\section{NOTIFICATIONS}

As previously noted, the Fair Practices Amendment Regulation requires an insurer to provide notification to its insured of the dispute resolution process under the IAA and the applicable limitation period for commencing action on the policy. The same regulation also requires a lawyer retained by the plaintiff in a claim arising from an automobile accident to notify the defendant's insurer, within 30 days of the action being commenced, that the plaintiff has retained counsel. ${ }^{86}$ In response, the defendant's insurer must advise the plaintiff's counsel as to the existence and liability limits of a motor vehicle liability policy issued to the defendant. ${ }^{87}$

Except as specifically excluded by regulation, the IAA approves the use of electronic transmission as a means of fulfiling a statutory obligation to provide a record to another person. ${ }^{88}$ The Fair Practices Amendment Regulation states that electronic transmission cannot be used for notices of cancellation and other specified notices relating to life insurance or accident and sickness insurance. ${ }^{89}$

\section{MISSED OPPORTUNITIES}

No matter how long legislative change takes, it is unrealistic to expect statutory reform to clarify every controversial or confusing point of law. However, there are a few problematic insurance law issues which relate specifically to the rights and obligations set out in Alberta's insurance legislation and which are, sadly, not addressed by the IAA. For example, three such questions are: (1) does the statutory provision which permits courts to exclude the application of unreasonable statutory terms apply to statutory conditions?; (2) does an insured breach its duty to report a material change where the insured fails to report the information, but the change is rectified before the loss and is not causally related to the loss?; and (3) what is the correct meaning of Statutory Condition number 2 in section 540 of the IAA (section 549 of the unamended Act)?

\section{A. “UNREASONABLE TERMS” AND STATUTORY CONDITIONS}

The general sub-part of the IAA adopts, without change, a provision from the fire insurance sub-part of the unamended Act, which states that a contract term is not binding on the insured if a court finds the term to be unjust or unreasonable. ${ }^{90}$ In Marche v. Halifax Insurance, ${ }^{91}$ the Supreme Court of Canada held that the equivalent provision in Nova Scotia's insurance legislation applied to prevent an insurer from relying on the insured's

IAA, ibid, ss 518(2), 518(3).

Ibid, s 518(4).

Fair Practices Amendment Regulation, supra note 3, s 5.1(1).

Ibid, s 5.1(2).

Supra note 1, s 547.

Supra note 3, s 5.4 .

See the IAA, supra note 1, s 545(1) and the unamended Act, supra note 4, s 552(1).

2005 SCC 6, [2005] 1 SCR 47 [Marche]. 
breach of a statutory condition. In response to the argument that the legislature could not logically have intended to mandate contract conditions by statute while simultaneously giving a court the option to deem those conditions unreasonable, the majority of the Court held that the relief provision applies to statutory conditions which, while prima facie reasonable, would give rise to an unjust result if applied in a particular instance. ${ }^{92}$ Two dissenting Supreme Court justices disagreed, finding that this interpretation is not supported by the structure and wording of the insurance legislation. ${ }^{93}$ Although the majority ruling of the Supreme Court provides a clear answer to the question of whether the relief provision can be used in regard to statutory conditions, the ruling leaves it up to courts to decide, on a case by case basis, what sort of circumstances would make the application of the statutory conditions unreasonable. The open-ended idea that the relief provision might apply in a given case leaves considerable uncertainty in the law for both insureds and insurers. Unfortunately, no attempt is made in the IAA to clarify this point or to rethink the Supreme Court's interpretation of the relief provision.

\section{B. The Duty to Report A MAterial ChANGE}

A central question put before the Supreme Court of Canada in Marche was whether an insurer can rely on an insured's failure to report a material change when the change is rectified prior to the loss occurring and is not causally related to the loss. The duty to report a material change is a mandated term of property and automobile insurance contracts under provincial legislation and, in Alberta, exists both under the unamended Act and the $I A A \cdot{ }^{94}$ As noted above, the majority of the Court resolved the Marche case by relying on a statutory relief provision to excuse the insured for its failure to report a material change in the circumstances of the case. In discussing the parameters of the statutory duty to report a material change, however, the Court was also divided as to whether the duty to report a material change applies at all where the change has been rectified prior to the loss and does not cause or contribute to the loss. In this regard, writing for the majority of the Court, Chief Justice McLachlin conceded that "Statutory Condition 4 is not a model of clarity." 55 Unfortunately, because the $I A A$ adopts this statutory condition without any modification, this lack of clarity remains.

\section{The Meaning of Statutory Condition Number 2}

The IAA adopts, as Statutory Condition number 2 in the general sub-part of the statute, the exact wording of Statutory Condition number 2 in the fire insurance sub-part of the unamended Act. This provision states:

$92 \quad$ Ibid at para 36 .

$93 \quad$ Ibid at paras 50, 111, Bastarache J, dissenting. For further discussion on this point of the case, see Barbara Billingsley, "Insurance Law Developments from the Supreme Court of Canada in 2005: Marche v. Halifax Insurance Company and Royal Bank of Canada v. State Farm Fire and Casualty Co.” (2006) 24:1 Can J Ins L 1.

94 In the unamended Act, supra note 4, see section 549, statutory condition 4 (regarding fire insurance) and section 614, statutory condition 1 (regarding automobile insurance). In the IAA, supra note 1 , see section 540, statutory condition 1 (regarding property insurance) and section 556, statutory condition 1 (regarding automobile insurance).

$95 \quad$ Marche, supra note 91 at para 43. 
Unless otherwise specifically stated in the contract, the insurer is not liable for loss or damage to property owned by any person other than the insured, unless the interest of the insured therein is stated in the contract. $^{96}$

Canadian courts have interpreted this provision to mean that an insured must have some degree of insurable interest in the insured property. ${ }^{97}$ While this judicial interpretation favours the insured, it is, arguably, not easily reconciled with the words of the provision as it is written. On its face, the provision seems to require an insured to advise the insurer if anyone other than the named insured has an ownership interest in the insured property. In other words, it reads like a disclosure provision, rather than an insurable interest provision. Further, as a disclosure provision, this statutory condition would play an important role in requiring an insured to advise the insurer if the insured does not have sole title to the property. Interpreted as an insurable interest provision, it does nothing more than codify the common law requirement that an insured have an insurable interest in the property which is the subject matter of the insurance policy. ${ }^{98}$ Unfortunately, no attempt is made in the IAA to modify the wording of this section to either more closely reflect the Supreme Court's interpretation or to clearly indicate that the legislative intention is not as suggested by the Court. $^{99}$

\section{Conclusion}

Does the $I A A$ achieve its purpose of clarifying insurance law and advancing consumer rights in regards to insurance contracts? Based on the foregoing review, I conclude that, in many ways, the $I A A$ does simplify insurance principles and better protects the interests of insureds. In some fundamental ways, however, the $I A A$ falls short of its goal. Of the changes that were made, notable points of deficiency relate to limitation periods and relief from forfeiture. Further, the IAA misses the opportunity to provide much needed clarification about the meaning of some provisions that are adopted from the unamended Act without change. Overall, the IAA may not be a long arrow with a short bow, but the Act, nonetheless, fails to directly hit its mark. 